\title{
マルチクリスタルモデルを用いた金微細接合部の応力分布解析*
}

\author{
川村好宏*1, 澄川貴志*2, 北村隆行*3 \\ 釘宮哲也*4, 川上崇*5
}

\section{Analysis of Stress Distribution in Au Micro-interconnection by Polycrystalline Models}

\author{
Yoshihiro KAWAMURA, Takashi SUMIGAWA*6, Takayuki KITAMURA, \\ Tetsuya KUGIMIYA and Takashi KAWAKAMI \\ ${ }^{* 6}$ Graduate School of Engineering, Kyoto University, \\ Yoshidahommachi, Sakyo-ku, Kyoto-shi, Kyoto, 606-8501 Japan
}

\begin{abstract}
A gold $(\mathrm{Au})$ micro-interconnection, which connects through-hole electrodes in a three-dimensional chip stacking LSI, is composed of several tens of grains. The anisotropic property of grains influences on the mechanical reliability if the size of the interconnection becomes small in comparison with the grain. In this study, the stress distribution in the Au micro-interconnection is invistigated by using the finite element method (FEM) analysis. The crystallographic structure of the Au microinterconnection is obtained by a three-dimensional simulation based on a nucleation and growth model. The FEM analysis shows that the stress is concentrated on the region near the microinterconnection/substrate interface edge and that a stress singularity exists there. The stress distribution of the micro-interconnection varies owing to the microscopic structural factor, which is due to the shape and crystallographic orientation of grains. It is found by statistical evaluations of plural analytical models that the stress variation nearly follows a normal distribution.
\end{abstract}

Key Words: Stress Concentration, Stress Singularity, Interface, Anisotropy, Finite Element Method, Multi-crystal, Statistical Evaluation, Au, Micro-interconnection

\section{1. 緒言}

近年, LSI（Large Scale Integration）に対しては高 速化・小型化を目的として, フリップチップ実装技術 (1)を発展させた三次元積層実装技術が注目されている. 三次元積層構造を有する LSI では, シリコンチップ同 士は金の微細接合によって接続される(1) (5) (図 1 参 照）。微細接合部は，上下をシリコンデバイスに，周 囲を樹脂などの補強層によって囲まれており，異種材 料との界面では変形のミスマッチに起因した応力集中 が予想されることから，破壊に関してとくに検討寸心゙ き箇所であると考えられる。 さらに, 回路基板に実装 されたパッケージに，振動や熱などによって反りが生 じると, 微細接合部には負荷が加わる. 巨視的には均 一な負荷が加わった場合であっても，微細接合部は数

* 原稿受付 2007 年 1 月 22 日

*1 京都大学大学院工学研究科(必606-8501 京都市左京区吉田 本町) [現：(株) デンソー(刈谷市昭和町 1-1) ].

$* 2$ 正員, 京都大学大学院工学研究科.

*3 正員, フェロー, 京都大学.

*4 正員, (株) 東芝研究開発センター(画212-8582 川崎市幸区 小向東芝町 1 ).

*5 正員, フェロー, (株) 東芝研究開発センター.

E-mail : sumigawa@cyber.kues.kyoto-u.ac.jp

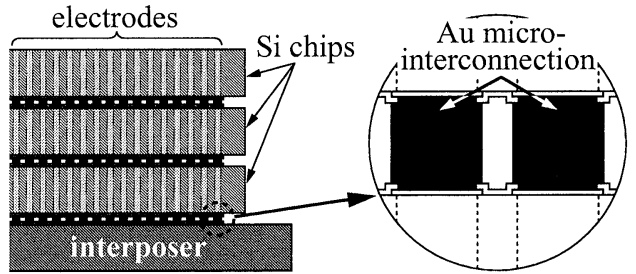

Fig. 1 3D stacking structure in a LSI chip.

えられる程度の少数の結晶粒で構成された多結晶体で あることから, 内部には各結晶粒の変形異方性に起因 した不均一な応力分布が生じる. とくに多結晶金属が 微小繰り返し変形を受ける場合, き裂の発生原因とな るひずみの局在化は，結晶粒の変形異方性を考慮に入 れた弾性応力場に支配される ${ }^{(6)}(8)$. よって, 微細接 合部に生じる応力分布を明らかにすることは, 強度信 頼性を考える上で重要である. 
そこで本研究では, 将来のターグットである $10 \mu \mathrm{m}$ サイズの金微細接合部を対象とし，異材界面や結晶粒 の影響を考慮した有限要素法 (Finite Element Method ; 以下 FEM と記寸) 解析を行い, 応力分布について 詳細な検討を行う。さらに, 結晶粒形状と結晶方位が 異なる複数のモデルに対する解析を実施し, 応力分布 のばらつきについて統計的な評価を行う.

\section{2. 解析モデルの作製}

本研究では図 1 に示した微細接合部の構造を摸し, 図 2 に示寸解析モデルを用いる. 微細接合部の形状を 一辺の長さが $10 \mu \mathrm{m}$ である立方体とし，接合体のシ リコンチップは剛体として取り扱い, 周囲の補強層は 除いて考える.また, 微細接合部を複数の結晶粒によ り構成した場合と，等方均質体とした場合の二種類の モデルを用意した，以下，前者をマルチクリスタルモ デル, 後者を均質体モデルと呼称する. マルチクリス タルモデルを構成する結晶粒は, 核生成・成長モデル に基づいた三次元シミュレーション ${ }^{(9) \sim(11)}$ によって作 製した。実施したシミュレーションの概略は以下の通 りである.

1: 結晶粒作製領域である微細接合部を一辺の長さ を $l$ とする微小立方体格子に分割する. 単位体積 あたりの結晶核数を表す核密度 $n_{\mathrm{r}}$ を決定し, 一 様乱数を用いて核に位置と結晶方位を与える（図 $3(\mathrm{a}))$.

2. 全ての結晶核の成長を同時に開始させ, その後一 定速度で成長させる（図 3(b)）

3. 結晶成長は微小立方体格子を順次占有していくこ とで表す。隣接する二つの微小立方体格子がそれ ぞれ異なる結晶によって占有された場合，格子間 の境界を暫定的な粒界と寸る（図 3(c)）。

4. 結晶粒が結晶粒作製領域を埋め尽くした後, 暫定 的に決定した階段状粒界を平面で近似した結晶粒 界に置き換える. (図 $3(\mathrm{~d})$ )

核密度 $n_{\mathrm{r}}$ は, 微細接合部の一辺長さ $L$ と, 内部に含 まれる結晶核の数 $\overline{n_{\mathrm{r}}}$ を用いて,

$$
n_{\mathrm{r}}=\overline{n_{\mathrm{r}}} / L^{3}
$$

として表される. 本解析では, 直径数十 $\mu \mathrm{m}$ 金微細接 合部の Electron Back Scattering Pattern 観測結果 ${ }^{(2)}$ を参考にして, $n_{\mathrm{r}}=0.02$ 個 $/ \mu \mathrm{m}^{3}$ とした. 結晶粒作 製領域を分割する微小立方体格子の一辺の長さ $l$ は, シミュレーションの結果に影響を与えない十分小さな 值を考慮して $l / L=10^{-2}$ とした。作製したマルチク リスタルモデルの結晶粒形状を図 4 亿示す. 本シミュ レーションにより, ランダムな形状と結晶方位を有す

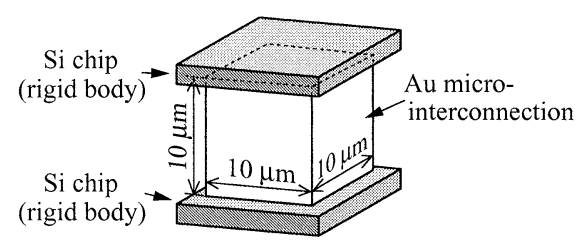

Fig. 2 Analytical model of an $\mathrm{Au}$ microinterconnection.

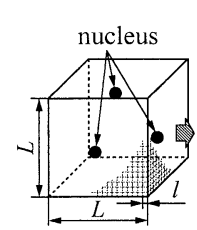

(a)

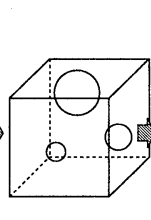

(b)

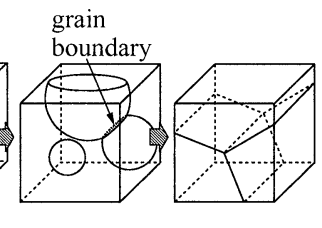

(c)

(d)
Fig. 3 Explanation of a three-dimensional simulation based on a nucleation and growth model.

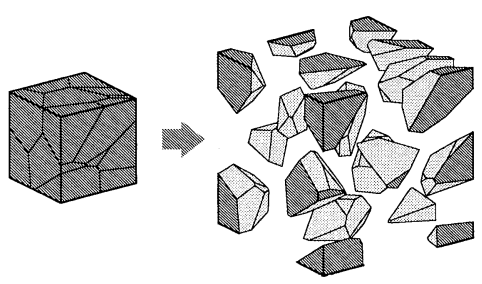

Fig. 4 Shape of component crystals in the multicrystalline model.

る複数の結晶粒で構成された微細接合部を作製するこ とができる.

\section{3. 解 析 条 件}

マルチクリスタルモデルを構成する結晶粒に対して は，弾性的性質の直交異方性を考慮して，金の弹性定 数 $C_{11}=186.0 \mathrm{GPa}, C_{12}=157.0 \mathrm{GPa}, C_{44}=42.0$ $\mathrm{GPa}$ をそれぞれの結晶方位に対応するよう座標変換し て代入した，一方，均質体モデルには，金多結晶体の ヤング率 $E=78.0 \mathrm{GPa}$ とポアソン比 $\nu=0.46$ を用 いた. FEM解析は, ABAQUS (version 6.5 - 1) を用 いて実施した。メッシュ分割には, 高精度のメッシュ 作製機能を有寸る MSC/Patran $2003 \mathrm{r} 2$ を使用し，応 力の集中が予想される粒界付近ではとくに細かい分割 を行ってある.最小メッシュの幅は, 微細接合部の一 辺の長さ $10 \mu \mathrm{m}$ に対して約 $5.25 \times 10^{-3} \mu \mathrm{m}$ である. また, 結晶粒界には完全接合条件を課した。境界条件 は図 5 に示すように，モデル下端を拘束し，上端に一 様な変位 $\Delta u_{z}$ を与えた．モデル上端に位置する節点 

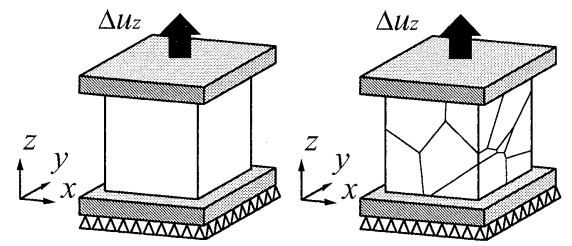

(a) Homogeneous model (b) Multi-crystalline model

Fig. 5 Boundary condition for FEM analysis.
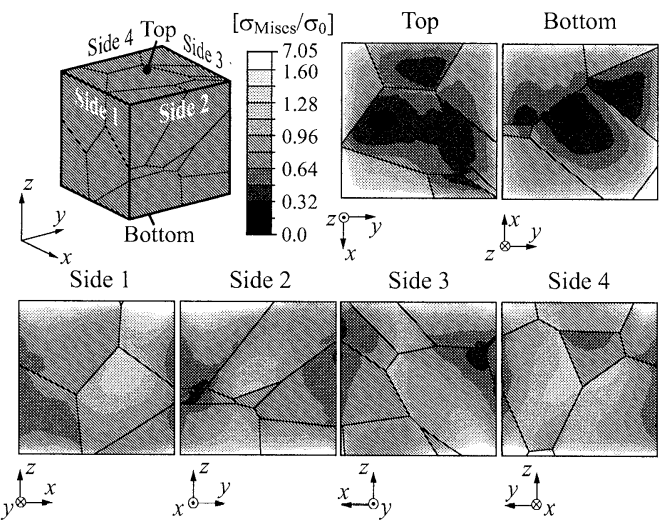

Fig. 6 Contour map of $\sigma_{\text {Mises }} / \sigma_{0}$ on each side surface of the multi-crystalline model.

の $z$ 方向垂直応力の平均值を公称応力 $\sigma_{0}$ とした.

\section{4. 結果および考察}

\subsection{Mises 相当応力の分布 図 6 は, マルチク}

リスタルモデルにおける Mises 相当忘力の分布を示す. 応力は公称応力 $\sigma_{0}$ で無次元化してある. また, 微細 接合部の四つの側面を Sides 1〜4，上面をTop，下面 をBottom として示してある. 高応力領域は異材界面 (Top, Bottom) と側面（Sides 1〜4）とが会合する 異材界面端近傍に集中しており，中でも微細接合部の 頂点近傍で高い值となっている。これは，フリーエッ ジ効果と呼ばれる巨視的構造要因に起因した忘力集中 であり, 均質体モデルの場合にも現れる.さらに, 異 材界面端と会合する結晶粒界近傍においても高い応力 值を示す領域が存在する。これは微視的構造要因であ る結晶粒間の変形拘束に起因したものであり，マルチ クリスタルモデル特有の応力状態である.

4.2 結晶学的なすべり系に働くせん断応力 金 属の塑性変形は, 主に結晶の最稠密面に沿ったすべり 変形によって起こる．金の結晶構造は面心立方型であ り，\{111\}面をすべり面，〈110 方向をすべり方向と する 12 の寸べり系を有している. 単結晶の場合, 結

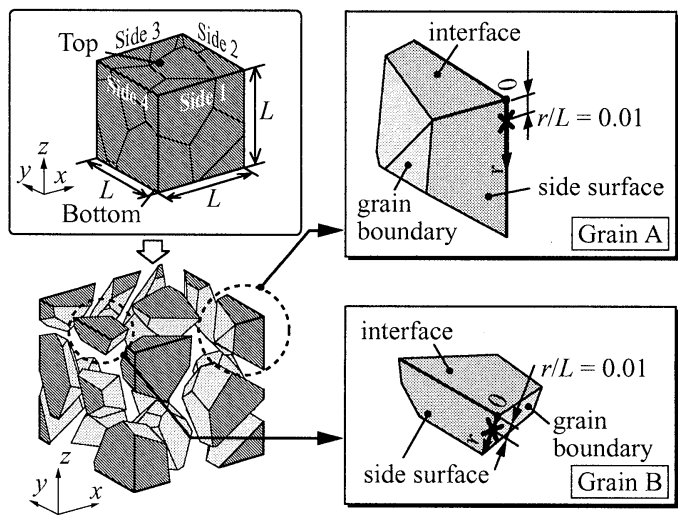

Fig. 7 Points where the stress is extracted in Grain A and Grain B.

晶方位と荷重方向によって決定されるシュミット因子 $\left(\tau / \sigma_{0}=\cos \phi \cdot \cos \lambda(\tau:\right.$ すべり方向への分解せん断志 力, $\sigma_{0}$ : 公称応力, $\phi:$ 引張軸とすべり面の法線のなす 角， $\lambda$ : 引張軸とす心゙り方向のなす角)）によってその すべり挙動を記述することができる。シュミット因子 は結晶方位と荷重軸によってのみ決定される因子であ り，物理的には，粒界の影響のない単結晶の各すべり 系に作用する無次元化分解せん断応力を意味する。一 方, 複数の結晶粒で構成されている多結晶の場合, 乙 れぞれの結晶粒のすべり挙動はシュミット因子には従 わない. マルチクリスタルモデルにおける Mises 相当 応力の分布（図 6）では，微細接合部頂点近傍や，異 材界面端と特定の結晶粒界との会合部近傍においてと くに高い応力が発生することが示された．そこで，異 材界面端に位置する結晶粒のうち, 微細接合部頂点の 結晶粒（図 7 中結晶粒 $\mathrm{A}$ ), および, 頂点ではない結晶 粒（図 7 中結晶粒 B）の二つの結晶粒に注目する。ま た, FEM 解析では界面に近接する要素は正確な応力 值を出力できない場合があることから，界面から $r / L$ $=0.01$ 離れた場所の応力を界面近傍の応力状態を代 表する応力として取り扱う。結晶粒 A において頂点か ら側面稜線に沿って $r / L=0.01$ 離れた場所（図 7 中 結晶粒 $\mathrm{A}$ 内 $\times$ 印) に位置する要素の応力と, 結晶粒 $\mathrm{B}$ において異材界面端と粒界との会合点から粒界に沿っ $\tau r / L=0.01$ 離れた場所 (図 7 中結晶粒 $\mathrm{B}$ 内 $\times$ 印) に位置する要素の忘力を抽出し, それぞれを各結晶粒 の 12 すべり系に対して分解した. 図 8 と図 9 には各 抽出点での分解せん断応力 (Resolved Shear Stress; 以下 $\tau_{\mathrm{rss}}$ と記す）を示す. 図中の值は公称応力 $\sigma_{0}$ を 用いて無次元化してある. また, すべり面は $\mathrm{A} \sim \mathrm{D} の$ 記号で, すべり方向は $1 \sim 3$ の数字で表してあり, そ 


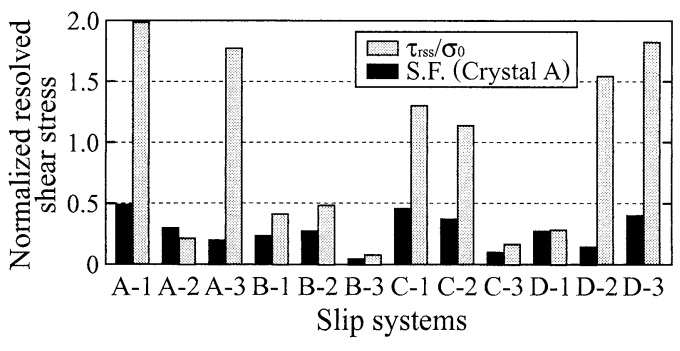

Fig. 8 Schmid factors (S.F.s) and $\tau_{\text {rss }} / \sigma_{0}$ on the 12 slip systems at the region near a vertex of the multi-crystalline model. (Grain A)

れぞれの結晶粒のシュミット因子も載せてある. 結晶 粒 A（図 8）において最も大きいシュミット因子を有 するすべり系はA-1である。 $\tau_{\mathrm{rss}} / \sigma_{0}$ についても，最 も値が大きいすべり系はA-1であるが，その值はシュ ミット因子の約 4 倍となっている. 前述のように, シュ ミット因子は粒界の影響のない単結晶における各すべ り系の無次元化分解せん断応力を意味し, 言い換える と, 異材界面や結晶粒界から離れた場所での $\tau_{\mathrm{rss}} / \sigma_{0}$ を代表する值である. 高サイクル疲労のようなひずみ 量の小さい変形では，すべり挙動は各結晶粒間の変形 拘束を考慮に入れた応力場によって記述することがで きる ${ }^{(6)}$ ( $(8)$ 。つまり, 本解析結果は, 結晶粒 $\mathrm{A}$ の頂点 近傍では A-1 すべり系のすべりが結晶粒内部に比べ て活発に活動することを示唆している.また, 微小繰 り返し変形を受ける金属では, すべりの活発な活動に 伴い固執すい゙り帯が形成されてき裂発生に至ることか ら, 結晶粒 $\mathrm{A}$ の応力抽出点近傍においてすい゙り $\mathrm{A}$ 面 に沿ったき裂の優先的発生が予想される. 一方, 結晶 粒 B（図 9）において最も大きいシュミット因子を有 するすべり系は D-3である， $\tau_{\mathrm{rss}} / \sigma_{0}$ の值が最も大き いすべり系は D-2 であり，D-3 のシュミット因子より 二倍以上大きい. 結晶粒 $\mathrm{B}$ に打ける応力抽出䇢所近傍 では, 結晶粒内部に比べて D-2すべり系のすべりが活 発に活動し，すべり面 Dに沿ったき裂が優先的に発生 することが予想される.

ひずみ量の小さい変形の場合, 多結晶体のすべり挙 動やそれに関連した疲労き裂の発生は, $\tau_{\mathrm{rss}} / \sigma_{0}$ の大 小を用いて議論することができる(6) (8).つまり, 12 すべり系の分解せん断応力のうち, 最大の值である最 大分解せん断応力 (Maximum Resolved Shear Stress ; 以下 $\tau_{\mathrm{mrss}}$ と記す) は微小繰り返し変形下でのき裂 の発生を支配する応力と考えられる. よって, 以下で は $\tau_{\mathrm{mrss}}$ を微細接合部の強度信頼性を支配する代表応 カとして議論を行う.

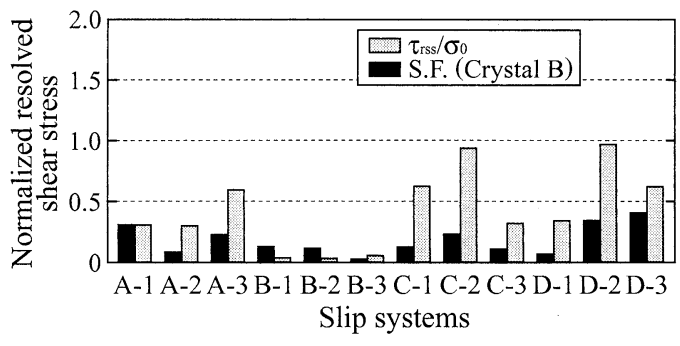

Fig. 9 Schmid factors (S.F.s) and $\tau_{\text {rss }} / \sigma_{0}$ on the 12 slip systems at the region near the intersection of a grain boundary and the interface edge in the multi-crystalline model. (Grain B)

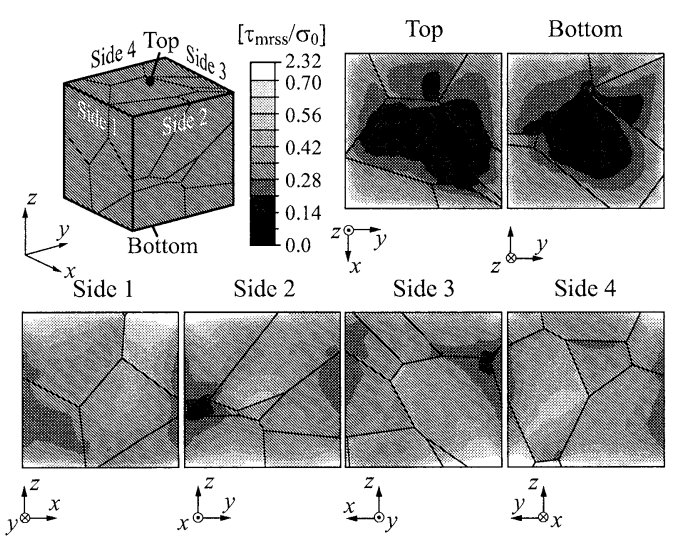

Fig. 10 Contour map of $\tau_{\text {mrss }} / \sigma_{0}$ on each side surface of the multi-crystalline model.

4.3 $\tau_{\mathrm{mrss}}$ の分布 図 10 にマルチクリスタルモ デルにおける $\tau_{\mathrm{mrss}}$ の分布を示す. 応力は公称応力 $\sigma_{0}$ を用いて無次元化してある. $\sigma_{\mathrm{Mises}} / \sigma_{0}$ の分布と同様 に, 異材界面端近傍において忘力集中が生じている. 図 11 は, マルチクリスタルモデルの異材界面 (Top, Bottom）において，界面端に沿った $\tau_{\mathrm{mrss}} / \sigma_{0}$ の分布 を示す. 図中の白三角は結晶粒界の位置, 黒三角は微 細接合部の頂点の位置を示している．微細接合部の頂 点近傍や特定の結晶粒界の近傍において高応力領域が 存在しており，これらの領域は注目して検討すべき箇 所であることがわかる.

図 12 は, マルチクリスタルモデルにおける 8 つの 頂点を原点とし, 原点から側面稜線に沿った $\tau_{\mathrm{mrss}} / \sigma_{0}$ の分布を示したものである. 図中では比較のために均 質体モデルの同位置での応力分布も載せてある，均質 体モデルでは, 最大せん断応力 $\tau_{\max }$ の值を用いてい る. 均質体モデルに生じる忘力分布は巨視的構造要因 


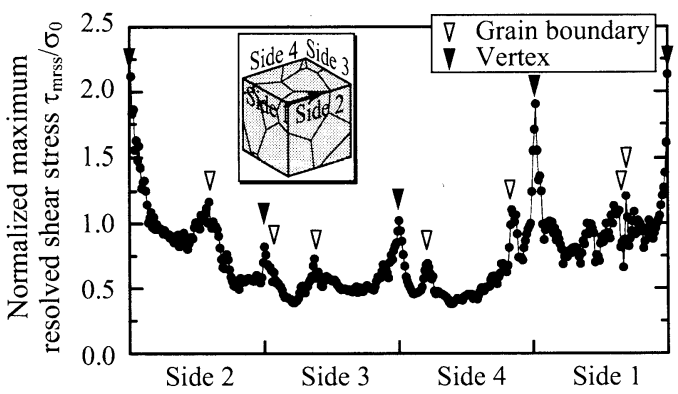

(a) Top

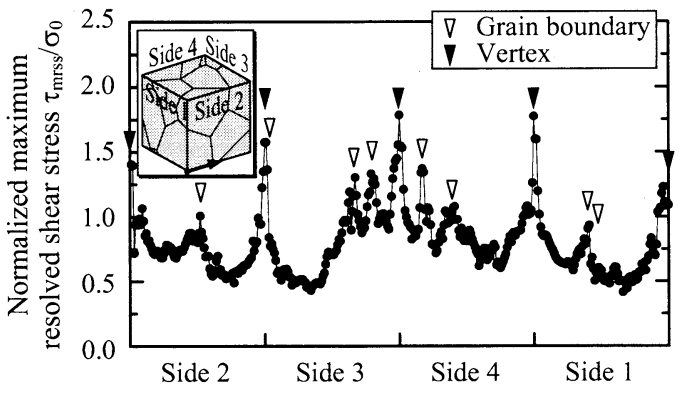

(b) Bottom

Fig. 11 Distribution of $\tau_{\mathrm{mrss}} / \sigma_{0}$ along the edge of the interface.

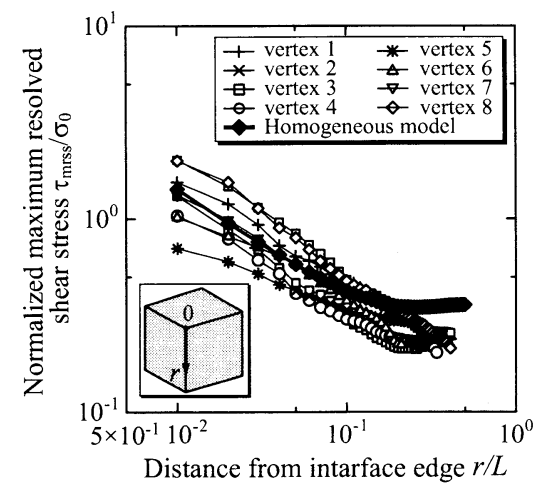

Fig. 12 Distribution curves of $\tau_{\mathrm{mrss}} / \sigma_{0}$ along the side edge from each vertex of the models.

のみに依存することから，モデル形状の対称性により 8 頂点からの応力分布曲線はいずれも同一となる．マ ルチクリスタルモデルでは各頂点ごとに応力分布曲線 は異なっており， $\tau_{\mathrm{mrss}} / \sigma_{0}$ の值には約 2 倍もの相違が ある。このように，巨視的には同一形状・同一境界条 件であっても，両モデルの応力分布には相違が現れる. また，すべての分布曲線において，次式で表される忘 力特異場が存在していると判断できる.

$$
\tau_{\mathrm{mrss}}=\frac{K}{r^{\lambda}}
$$

$K$ は特異場パラメータと呼ばれる応力特異場の強さを 表すパラメータ， $\lambda$ は特異性のオーダーである。均質 体モデルでは $\lambda=0.569$ である. マルチクリスタルモ デルでは，頂点のごく近くをのぞいた $r / L=0.02 〜$ 0.1 の範囲において，それぞれの分布曲線の $\lambda$ 值は概

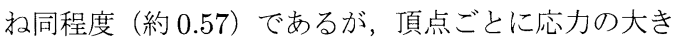
さが異なっている，つまり，微視的構造因子は主に応 力拡大の程度に対して影響を及ぼす.また，均質体モ デルの応力分布曲線は, マルチクリスタルモデルの応 力分布曲線のばらつきのほぼ中心に位置している。 マ ルチクリスタルモデルに生じる応力場を評価する際, 均質体モデルの結果はひとつの基準を与えるものであ ることがわかる。

4.4 応力分布に影響を及ぼす構造要因 界面端 近傍の応力分布にばらつきには, 巨視的構造要因と微 視的構造要因とが共に作用している. 巨視的構造要因 による応力分布のばらつきは，応力の抽出位置に起因 する，図 13 に示すように，巨視的構造要因のみを有す る均質体モデルにおいて, 異材界面端上の異なる位置 に $\mathrm{A}$ 点と $\mathrm{B}$ 点を設置する． A 点と $\mathrm{B}$ 点からモデル側 面鉛直方向に沿った最大せん断応力をそれぞれ $\tau_{\max , \mathrm{A}}$ と $\tau_{\max , \mathrm{B}}$ とし, 図 14 にその分布を示す. 両者はとも に異材界面端から同方向への応力分布であるが，異 なった分布曲線となっている. $r / L=0.02 \sim 0.08$ に おける両曲線の $\lambda$ は, $\mathrm{A}$ 点で $0.535, \mathrm{~B}$ 点で 0.471 で ある. $\mathrm{B}$ 点に比べて $\mathrm{A}$ 点の $\lambda$ が大きくなっているの は，異材界面端と会合する頂点では，二次元的な界面 端より強い応力特異場が現れることが原因である ${ }^{(12)}$. また， $\tau_{\max , \mathrm{B}}$ の分布では，微細接合部中央部 $(r / L=$ 0.5）付近で応力が上昇している. 本解析では，モデル は中央部付近にくびれを生じ，表面は凹形状となる。 $\tau_{\max , \mathrm{B}}$ を抽出した領域では，凹形状の曲率が最大と なる領域が中央部ではなく異材界面寄りに存在する. 解析ではモデルに引張り変形を与えているが，凹形状 の曲率が大きくなると, 曲げ変形に起因した圧縮応力 成分が増加することから， $\tau_{\max , \mathrm{B}}$ は中央部から離れ た領域で最小值を示す， $\tau_{\max , \mathrm{A}}$ を抽出した領域では, 凹形状の曲率が最大となる領域はほぼモデル中央部に 存在する.これは, $\tau_{\max , \mathrm{A}}$ の抽出領域が, 微細結合部 の稜線の影響により $\tau_{\max , \mathrm{B}}$ を抽出した領域よりも剛 性が高くなっていることが原因である。一方，微視的 構造要因による忘力分布のばらつきは, 結晶粒形状や 結晶方位といった結晶構造に起因しており，マルチク リスタルモデルのみに存在する. 図 12 中の応力分布 


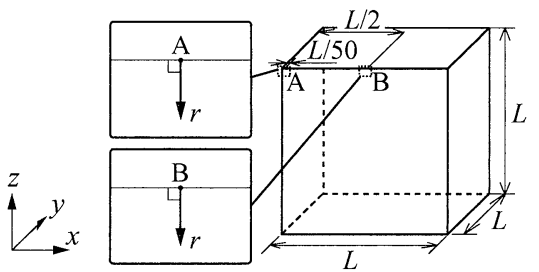

Fig. 13 Points defined on a side surface of the homogeneous model.

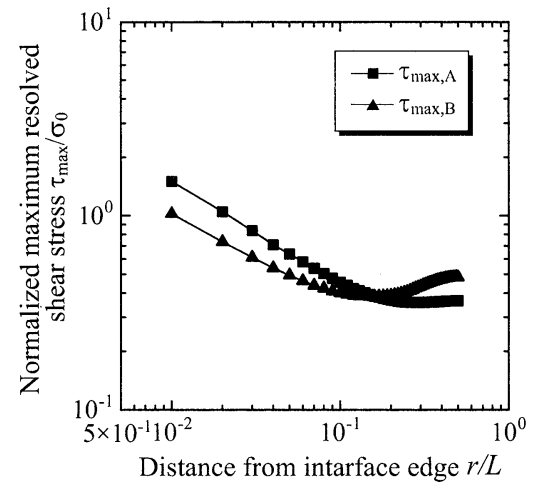

Fig. 14 Distribution curves of $\tau_{\max } / \sigma_{0}$ at points $\mathrm{A}$ and $\mathrm{B}$ in the homogeneous model.

のばらつきは, 微視的構造要因によるものであり, 巨 視的構造要因のみの応力分布を表す均質体モデルの值 を中心にばらついている.

\section{5 微視的構造要因による応力分布のばらつきの}

\section{統計的評価}

4.5.1 微視構造因子 $\alpha$ 微視的構造因子による 応力分布のばらつきは, 結晶粒の形状や分布に依存 する. 微小接合部内の結晶粒形状や結晶方位はランダ ム性を有することから, ある特定のモデルの解析結果 のみでは十分な情報を得ることはできず，複数の解析 データを用いて統計的な評価を行う必要がある.そこ で, 図 4 で示したモデルとは異なる結晶粒形状と結晶 方位を有する 9 通りのマルチクリスタルモデルを作製 し, 計 10 通りの解析結果を用いて微視的構造要因に起 因する応力分布のばらつきについて統計的な評価を実 施する. 9 つモモ゙ル作製に関する三次元シミュレー ション条件およびFEM 解析条件は, 図 4 に示したモ デルと同一である，ところで，マルチクリスタルモデ ルに生じる応力分布には, 巨視的構造要因と微視的構 造要因が複合的に作用している. 微視的構造要因の影 響を抽出するために，マルチクリスタルモデル上の応 力を均質体モデル上の対応する位置の応力で除した,

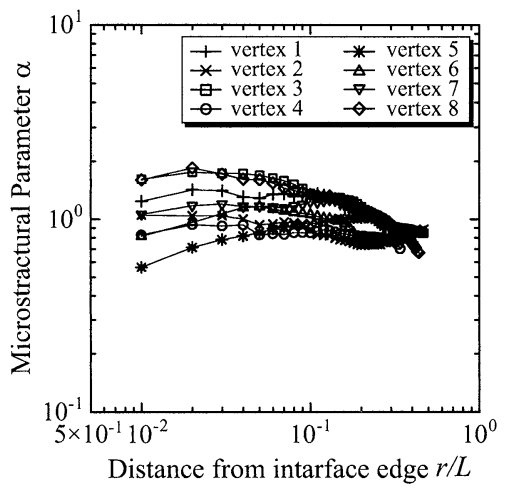

Fig. 15 Distribution curves of $\alpha$ along the side edge from each vertex of the multi-crystalline model.

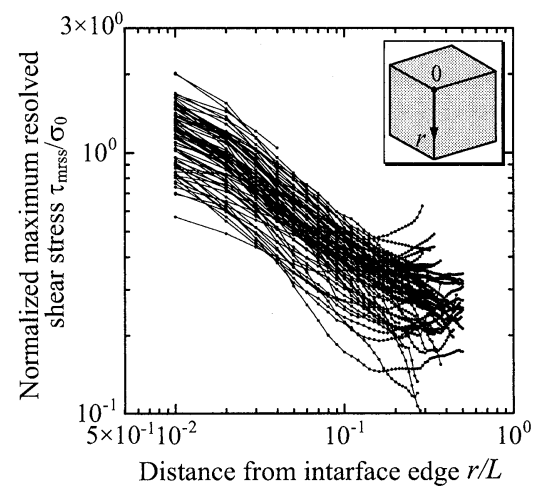

Fig. 16 Distribution curves of $\tau_{\mathrm{mrss}} / \sigma_{0}$ along the side edge from each vertex of 10 multicrystalline models.

次式で示す微視構造因子 $\alpha$ を定義した.なお添え字の homoは均質体モデル (homogeneous model) を, multi はマルチクリスタルモデル (multi-crystalline model) を指す.

$$
\alpha=\frac{\tau_{\mathrm{mrss}}^{\mathrm{multi}} / \sigma_{0}^{\mathrm{multi}}}{\tau_{\mathrm{mrss}}^{\text {homo }} / \sigma_{0}^{\text {homo }}}
$$

図 15 には，図 4 で示したマルチクリスタルモデルの 8 頂点を原点とし，その原点から側面稜線に沿った $\alpha$ の分布を示す. 特異場の成立している $r / L=0.02 \sim$ 0.08 の範囲では，各曲線の傾きは水平を中心にばらつ いている。これは, 式 (2) で表される応力特異場にお いて，その傾きを表す $\lambda$ に与える微視的構造要因の影 響が小さいことを示している。ただし，曲線間では， $\alpha$ の值は $0.5 \sim 2.0$ の範囲でばらついている. 


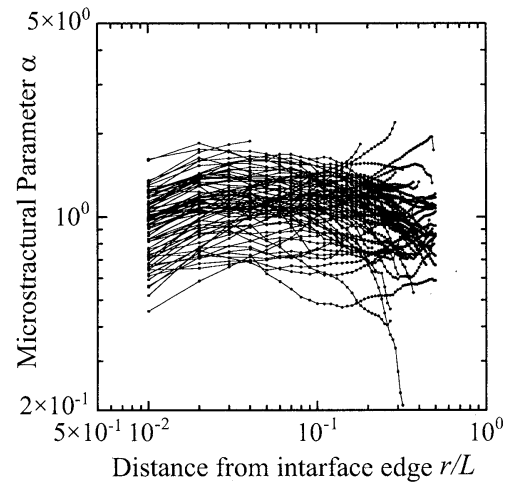

Fig. 17 Distribution curves of $\alpha$ along the side edge from each vertex of 10 multi-crystalline models.
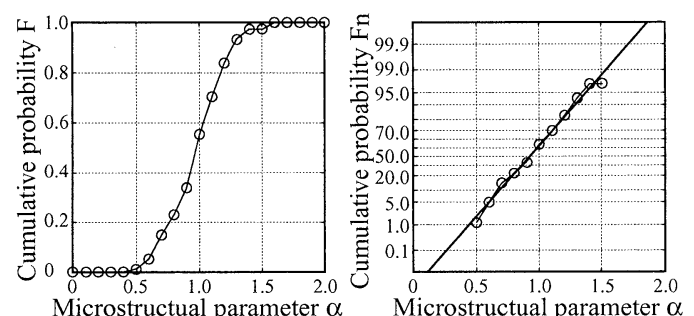

(a) Cumulative probability plots (b) Normal probability plots

Fig. 18 Cumulative probability plots and normal pribability plots of $\alpha$.

\subsection{2 頂点近傍の応力分布 図 16 には, 全 10} 通りのマルチクリスタルモデルにおいて，それぞれの モデルの 8 頂点を原点とし, 原点から側面稜線に沿つ た $\tau_{\mathrm{mrss}} / \sigma_{0}$ の分布曲線を示す. 曲線の総数は 80 であ る.いずれの曲線においても $r / L=0.02 \sim 0.08$ の範 囲では式 (2) で表される特異場が成立している. 図 17 は微視的構造因子 $\alpha$ の分布曲線を示寸. 曲線のばらつ きは，均質体モデルを表す $\alpha=1.0$ を中心にほぼ対称 となっている.また，分布の幅は $r / L$ によらずほぼ一 定であり, 微視的構造要因による応力拡大の程度はい ずれの稯線上でも均一であることを示している， $r / L$ $=0.01$ における $\alpha$ の值を各頂点の代表值とし，ばらつ きに対して統計的評価を実施する. 図 18(a) は, $r / L$ $=0.01$ での $\alpha$ の累積確率密度分布を示す. 分布の平 均值は 0.975 であり, 均質体モデルに生じる応力分布 ( $\alpha=1.0)$ がばらつきの中心となっている. 分布の最 小值は 0.386 , 最大值は 1.548 である. 最小值もしく は最大值付近では分布の傾きが小さくなる反面, 1.0 付近では分布の傾きが大きい。これは，值が平均值付

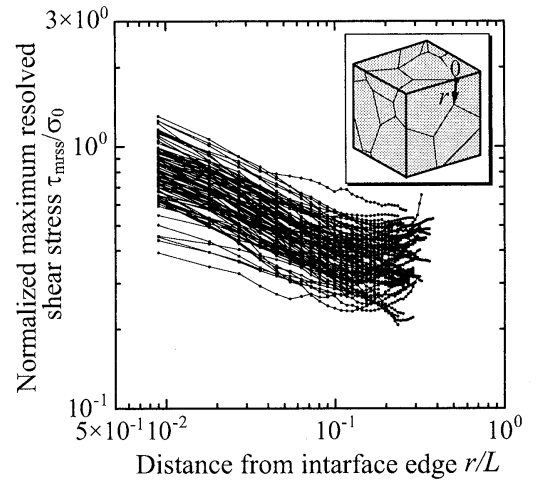

Fig. 19 Distribution curves of $\tau_{\mathrm{mrss}} / \sigma_{0}$ along the grain boundary from intersections of the grain boundaries and interface edges in 10 multi-crystalline models.

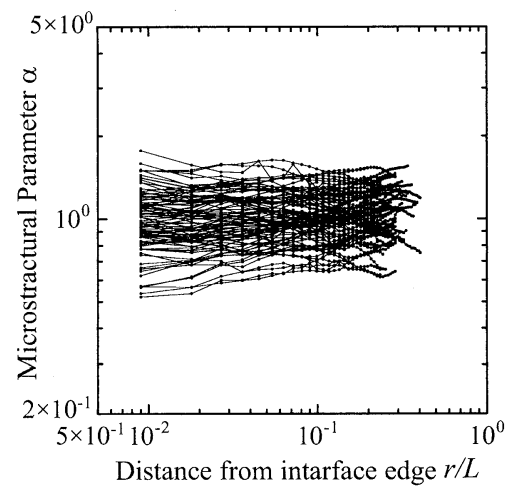

Fig. 20 Distribution curves of $\alpha$ along the grain boundary from intersections of grain boundaries and interface edges in 10 multicrystalline models.

近に集中していることを示している. 図 18(b) は, 図 18(a) に示した累積確率密度分布を正規確率分布紙上 にプロットしなおしたものである. 分布が正規確率分 布に従う場合, 正規確率分布紙上でのプロットは直線 関係となる，中空印の分布はほぼ直線であり，ばらつ きが正規分布に近いことが分かる．正規分布実線を用 いて近似した場合の平均值 $m$ 及び標準偏差 $s$ は, そ れぞれ 0.979 および 0.235 である。

4.5.3 結晶粒界に沿った応力分布 図 19 には全 10 通りのマルチクリスタルモデルにおいて，異材界 面端と結晶粒界との会合部を原点とし，それぞれの結 晶粒界に沿った $\tau_{\mathrm{mrss}} / \sigma_{0}$ の分布を示す. 対象となる粒 界の総数は 99 である. どの粒界についても， $r / L=$ 

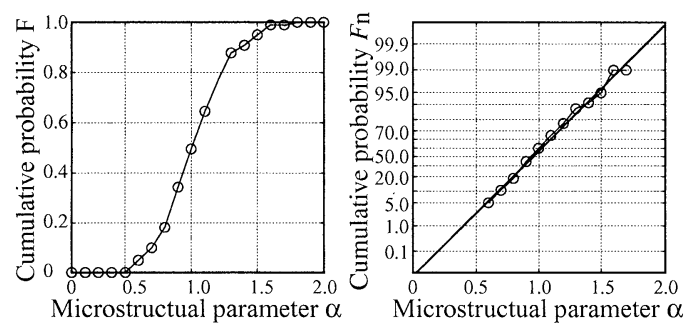

(a) Cumulative probability plots (b) Normal probability plots

Fig. 21 Cumulative probability plots and normal pribability plots of $\alpha$.

$0.01 \sim 0.08$ の範囲では式 $(2)$ で表される特異場が成立 している. 図 20 に微視構造因子 $\alpha$ の分布曲線を示す. 基本的な傾向は頂点近傍の場合と等しく, 応力拡大の 程度は同一粒界上で等しい. 図 $21(\mathrm{a})$ に $r / L=0.01$ における微視構造因子 $\alpha$ の累積確率密度分布を示す. 分布の平均值は 1.0 , 分布の最小值は 0.521 , 最大值は 1.770 である. 図 21(b) は, 図 21(a) に示した累積確率 密度分布を正規確立分布紙上にプロットしなおしたも のである.中空印の分布はほぼ直線であり，ばらつき が正規分布に近いことが分かる. その分布を正規分布 実線で近似した場合の平均值 $m$ および標準偏差 $s$ は, それぞれ 1.023 および 0.268 である。

\section{5. 結言}

三次元積層構造を有する LSI に用いられる金微細接 合部を対象として, 複数の結晶粒で構成されたマルチ クリスタルモデルを用いて有限要素法解析を実施し, 応力分布について評価を行った. 得られた結果を以下 に示す.

1. 微細接合部と基板とが接合された異材界面端近傍 において応力が集中し，とくに微細接合部の頂点 近傍で高い応力集中が生じる.これらは巨視的構 造要因によるものである，また，界面端近傍には 特異応力場が存在する.

2. 異材界面端と特定の結晶粒界の会合部近傍にお いても高応力領域が存在する。これは結晶粒間の 変形拘束に起因した微視的構造要因によるもので ある.

3. 異材界面端近傍の特異応力場において, 特異性の オーダー $\lambda$ にほほす微視的構造要因の影響は小さ い. 微視的構造要因が忘力分布に与える主な効果 は, 応力を一様に増加もしくは減少させることで ある・

4. 金微細接合部表面の応力分布は微視的構造因子の 影響によりばらつきを生じるが，そのばらつきは，
均質体モデルで計算される応力の約 2 倍を上限と する.

5. 微細接合部に生じる応力分布のばらつきは, 巨視 的構造要因と微視的構造要因の両者に起因して いる.

6. 微視的構造要因に起因した応力分布のばらつきは 正規分布に従う.

\section{文献}

(1) Ramsay, E. et al., Three-dimensional imaging of a silicon flip chip using the two-photon optical-beam induced current effect, Applied Physics Letters, Vol.81, No.1 (2001), pp.7-9.

(2) Takahashi, K. et al., Ultra-high-density interconnection technology of three-dimensional packaging, Microelectronics Reliability, Vol.43, No.8 (2003), pp.1267-1279.

(3) Tanida, K. et al., Au bump interconnection in 20 $\mu \mathrm{m}$ pitch on $3 \mathrm{D}$ chip stacking technology, Japanese Journal of Applied Physics, Vol.42, No.10 (2003), pp.6390-6395.

(4) Tanida, K. et al., Au bump interconnection with ultrasonic flip-chip bonding in $20 \mu \mathrm{m}$ pitch, Japanese Journal of Applied Physics, Vol.42, No.4B (2001), pp.2198-2203.

(5) Wang, Q. et al., Reliability of Au bump - $\mathrm{Cu}$ direct interconnections fabricated by means of surface activated bonding method, Microelectronics Reliability, Vol.43, No.5 (2003), pp.751-756.

(6) Kitamura, T. et al., Slip behavior and local stress near grain boundary in high-cycle fatigue of copper polycrystal, JSME International Journal, Vol.47, No.2 (2004), pp.92-97.

(7) Sumigawa, T. et al., Slip behaviour near a grain boundary in high-cycle fatigue of poly-crystal copper, Fatigue \& Fracture of Engineering Materials \& Structures, Vol.27, No. 6 (2004), pp.495-503.

(8) Sumigawa, T. and Kitamura, T., Nucleation of slip bands near twin boundary in high-cycle fatigue, JSME International Journal, Vol.47, No.2 (2004), pp.98-105.

(9) Mori, Y. and Miura, I., Morphology Change of Grain Structure by a Uniform Nucleation and Growth Model (in Japanese), Journal of Japan Institute of Metals, Vol.46, No.2 (1982), pp.224-232.

(10) Johnson, W.A. and Mehl, R.F., Reaction kinetics in processes of nucleation and growth, Transactions of the American Institute of Mining and Metallurgical Engineers, Vol.135 (1939), pp.416-458.

(11) Mahin, K.W. et al., Comparative-Analysis of the Cellular and Johnson-Mehl Microstructures through Computer-Simulation, Acta Metallurgica, Vol.28, No.4 (1980), pp.443-453.

(12) Koguchi, H. et al., Analysis for stress singularity field at a vertex in three-dimensional bonded structures, JSME International Journal, Vol.42, No.1 (1999), pp.80-89. 